www.jmscr.igmpublication.org

Impact Factor 5.84

Index Copernicus Value: 83.27

ISSN (e)-2347-176x ISSN (p) 2455-0450

crossref DOI: https://dx.doi.org/10.18535/jmscr/v5i1.135

Journal Of Medical Science And Clinical Research

\title{
Biochemical Evaluation of Dietary Onion as a Hypoglycemic Agent in Rats
}

\author{
El-Khedr Mohamed Mostafa El-gamal
}

Dept of Chemistry, Faculty of Science and Arts at Baljurashi, Al-Baha University, Kingdom of Saudi Arabia

\begin{abstract}
Diabetes mellitus is one of the serious global health problems affecting a significant proportion of both developed and developing countries. Overproduction of free radicals and oxidative stress has been associated with the development of diabetic complications. The present study was carried out to investigate the effects of onion (Allium cepa) juice on biochemical parameters, enzyme activities and lipid peroxidation in alloxan-induced diabetic rats. Alloxan $(130 \mathrm{mg} / \mathrm{kg} \mathrm{BW})$ was administered as a single dose to induce diabetes. Three (3) groups of rats $(n=8)$ were used; group 1 was normal control while group 2 was used as diabetic test group and group 3 was diabetic group that received A dose of $1 \mathrm{ml}$ of onion juice $/ 100 \mathrm{~g}$ body weight (equivalent to $0.4 \mathrm{~g} / 100 \mathrm{~g} \mathrm{BW}$ ) was orally administered daily to alloxan-diabetic rats for four weeks. The levels of glucose, urea, creatinine and bilirubin were significantly $(p<0.05)$ increased in plasma of alloxan-diabetic rats compared to the control group. Aspartate aminotransferase (AST), alanine aminotransferase $(A L T)$, lactate dehydrogenase $(L D H)$, alkaline and acid phosphatases $(A l P, A c P)$ activities were significantly $(p<0.05)$ increased in plasma and testes of alloxan-diabetic rats, while these activities were decreased in liver compared with the control group. Brain LDH was significantly $(p<0.05)$ increased. The concentration of thiobarbituric acid reactive substances and the activity of glutathione S-transferase in plasma, liver, testes, brain, and kidney were increased in alloxan diabetic rats. Treatment of the diabetic rats with repeated doses of onion juice could restore the changes of the above parameters to their normal levels. The present results showed that onion juice exerted antioxidant and antihyperglycemic effects and consequently may alleviate liver and renal damage caused by alloxan-induced diabetes

Keywords: Rats; Alloxan; Onion; Biochemical parameters; Enzymes; Lipid peroxidation.
\end{abstract}

\section{Introduction}

Diabetes is the most common metabolic disorder out of various lifestyle diseases associated with many complications such as diabetic ketoacidosis, hyperosmolar coma, cardiovascular problems, kidney failure, eye damage, nonketotic hyperosmolar coma, and foot ulcers. The condition develops due to abnormalities in carbohydrate metabolism and insulin synthesis resulting in high blood sugar with symptoms such as elevated hunger and thirst, polyuria, glycosuria, and lethargy. The World Health Organization ${ }^{[1]}$ has predicted that the worldwide number of patients with diabetes will double by the year 2025, from the current number of approximately 150 to 300 million. Studies have shown that during the manifestations of diabetes there is an enhanced production of free radicals and reactive oxygen species (ROS), which enhanced lipid peroxideation, damage to DNA, and protein degradation. 
In type 1 diabetes, ROS are involved in $\beta$-cell dysfunction initiated by autoimmune reactions and inflammatory cytokines ${ }^{[2]}$. In type 2 diabetes, ROS activate $\beta$-cell apoptotic pathways, impair insulin synthesis, and also contribute to insulin resistance ${ }^{[3,4]}$. Despite the great strides made in the understanding and management of diabetes, the disease and disease related complications are increasing unabatedly due to multiple defects in its pathophysiology ${ }^{[5]}$. Dietary factors play a key role in the development of various human diseases, including cardiovascular andother metabolic diseases, atherosclerosis, hyperlipidemia, thrombosis, hypertension and diabetes ${ }^{[6]}$. Medicinal plants continue to provide valuable therapeutic agents, in both modern medicine and in traditional system. The doubts about the efficacy and safety of the oral hypoglycemic agents have prompted a search for safer and more effective drugs in the treatment of diabetes ${ }^{[7]}$. In spite of the factthat insulin has become one of the most important therapeutic agents known to medicine, researchers have been making efforts to find insulin substitutes from synthetic or plant sources for the treatment of diabetes. Many herbs have remained as an alternative to conventional therapy especially in poor areas where insulin is not readily available ${ }^{[8]}$. Allium species such as onions are used as foodstuff, condiment, flavoring, and folk medicine. Onion has attracted particular attention of modern medicine because of its widespread health use around the world, and the cherished belief that it helps in maintaining good health, warding off illnesses and providing more vigor. The biological responses of onion have been largely attributed to (i) reduction of risk factors for cardiovascular diseases and cancer, (ii) stimulation of immune function, (iii) enhanced detoxification of foreign compound, (iv) hepatoprotection, (v) antimicrobial effect and (vi) antioxidant effect ${ }^{[6]}$. Onion was also a popular folk remedy. It is rich in flavonoids such as quercetin and sulfur compounds, such as allyl propyl disulphide that have perceived benefits to human health ${ }^{[9]}$. In addition, onion is rich in sulfur containing compounds mainly in the form of cysteine derivatives, viz. S-alkyl cysteine sulfoxides which are decomposed the enzyme allinase into a variety of volatile compounds such as thiosulfinates and polysulfides during extraction. These compounds possess antidiabetic, antibiotic, hypocholesterolaemic, fibrinolytic, and various other biological effects. In addition to volatile substances in alliums, there are nonvolatile sulfur-containing peptides and proteinswhich have been shown to have potential health benefits ${ }^{[10]}$. Therefore, the purpose of the present study was to examine the influence of oral administration of onion on the levels of free radicals, biochemical parameters, and the activities of some enzymes in plasma and different tissues of alloxan-induced diabetic rats.

\section{Materials and Methods}

Fresh onion (Allium cepaLinn) bulbs were obtained from the local market in New Domiatta, Egypt and cut into small pieces. About $250 \mathrm{ml}$ of distilled water per $100 \mathrm{~g}$ of onion were added and crushed in a mixing machine. The resultant slurry was squeezed and filtered through a fine cloth and the filtrate was quickly frozen until used. .Alloxan (hydrate) LR, C4H2N2O4. H2O, was purchased from Sigma-Aldrich Chemical (St. Louis, MO, USA) by Gamma trade Company (Cairo). Alloxan was dissolved in saline solution $(0.9 \%$ sodium chloride, pH7). The dose of alloxan used was $130 \mathrm{mg} / \mathrm{kg} \mathrm{BW}$ as a single dose ${ }^{[11]}$.

\section{Animals}

Twenty-four adult male albino rats (100-160 g) were obtained from the Animal House of the Faculty of Medicine (Domiatta), University of AlAzhar, Egypt. The animals were housed in standard cages under 12-hour light/dark cycle maintained on a standard feed and water ad libitum. Rats were fed pellets

consisted of $30 \%$ berseem hay, $25 \%$ yellow corn, $26.2 \%$ wheat bran, $14 \%$ soybean meal, 3\% molasses, $1 \% \mathrm{CaCl} 2,0.4 \% \mathrm{NaCl}, 0.3 \%$ mixture of minerals and vitamins $(0.01 \mathrm{~g} / \mathrm{kg}$ diet of vitamin 
E), and $0.1 \%$ methionine. The chemical analysis of the pellets ${ }^{[12]}$ showed that they contained $17.5 \%$ crude protein, $14.0 \%$ crude fiber, $2.7 \%$ crude fat and $2200 \mathrm{Kcal} . / \mathrm{kg}$ diet. After one weeks of acclimation, animals were divided into two groups. The first group (8 rats) was used as control and received double distilled water as vehicle. The second group (16 rats) was injected subcutaneously (s.c.) with a single dose of alloxan $(130 \mathrm{mg} / \mathrm{kg} \mathrm{BW})$, and divided into two subgroups (8 rats per each) after stabilization of diabetes for one week (animals having fasting blood glucose concentration $\geq 200 \mathrm{mg} / \mathrm{dL} \quad(11.1 \mathrm{mmol} / \mathrm{L})$ were considered diabetic and used for the investigation). The first subgroup was kept as diabetic. The second subgroup received $1 \mathrm{ml}$ onion juice/100g BW/day by gavage for four weeks. Prior to administration of alloxan, the animals were fasted for $12 \mathrm{~h}$ with free access drinking water. At the end of the experimental period, animals were sacrificed. Serum was obtained for further biochemical analysis.

\section{Enzyme Assessments}

At the end of the experimental period, rats were fasted for $12 \mathrm{~h}$, and then sacrificed by cervical decapitation and fasting blood samples were collected from the sacrificed animals in tubes with heparin. Plasma samples were obtained by centrifugation at $860 \mathrm{~g}$ for $20 \mathrm{~min}$ and stored at $20 \mathrm{oC}$ till measurements. Also, liver, testes, kidney, and brain were immediately removed and washed using chilled saline solution. Tissues were minced and homogenized (10\% w/v), separately, in ice cold $1.15 \% \mathrm{KCl}-0.01 \mathrm{M}$ sodium, potassium phosphate buffer ( $\mathrm{pH}$ 7.4) in a Potter-Elvehjem type homogenizer. The homogenate was centrifuged at $10,000 \mathrm{~g}$ for $20 \mathrm{~min}$ at $4 \mathrm{oC}$, and the resultant supernatant was used for different enzyme assays. Plasma, liver and testes alanine aminotransferase (ALT; EC 2.6.1.2) and aspartate aminotransferase (AST; EC 2.6.1.1) activities were assayed by the method of Reitman and Frankel (1957) ${ }^{[13]}$. Plasma, brain, liver and testes lactate dehydrogenase (LDH, EC1.1.1.27) activity was determined by the method of Cabaud and Wroblewski (1958) ${ }^{[14]}$. Alkaline phosphatase (AlP; EC 3.1.3.1) activity was measured at $405 \mathrm{~nm}$ by the formation of paranitrophenol from paranitrophenylphosphateas a substrate ${ }^{[15]}$. Acid phosphatase (AcP; EC 3.1.3.2) activity was measured using the method of Moss (1984) ${ }^{[16]}$. Plasma, liver,brain, testes and kidney glutathione S-transferase (GST; EC 2.5.1.18) activity was determined according to Habig et al. (1974) ${ }^{[17]}$, using para-nitrobenzylchlorideas a substrate. Thiobarbituric acid-reactive substances (TBARS) were measured in plasma, liver, brain, testes and kidney by using the method of Tappel and Zalkin (1959) ${ }^{[18]}$. Protein concentration in liver, testes, brain and kidney supernatants was assayed by the method of Lowry et al. (1951) ${ }^{[19]}$ using bovine serum albumin as a standard.

\section{Biochemical Assays}

Stored plasma samples were analyzed for glucose level by using the method of Trinder (1969) ${ }^{[20]}$. Plasma urea, creatinine and total bilirubin concentrations were determined by the methods of Patton and Crouch (1977) ${ }^{[21]}$; Henry et al. (1974) ${ }^{[22]}$ and Pearlman and Lee (1974) ${ }^{[23]}$, respectively.

\section{Statistical analysis}

Data were analyzed as a completely randomized design [24] using the General Linear Model procedure ${ }^{[25]}$. Means were statistically compared using least significant difference (LSD) test at 0.05 significant level ${ }^{[24]}$.

\section{Results}

The effects of oral administration of onion juice on plasma glucose, urea, creatinine and total bilirubin are presented in Table 1. The experimentally induced-diabetes increased $(\mathrm{p}<$ 0.05 ) the level of plasma glucose by $199 \%$ of control level (Table 1). 
Table 1: Plasma glucose, bilirubin, creatinine and urea levels in control, diabetic, and diabetic treated male rats with onion $(\mathrm{O})($ Means $\pm \mathrm{SE}$ )

\begin{tabular}{|l|c|c|c|}
\hline $\begin{array}{l}\text { Parameters } \\
(\mathrm{mg} / \mathrm{dl})\end{array}$ & Control & Diabetic & Diabetic + O \\
\hline Glucose & $101 \pm 5.64^{\mathrm{b}}$ & $293 \pm 7.20^{\mathrm{a}}$ & $85 \pm 6.10^{\mathrm{b}}$ \\
\hline Bilirubin & $0.83 \pm$ & $1.34 \pm$ & $0.82 \pm$ \\
& $0.070^{\mathrm{b}}$ & $0.083^{\mathrm{a}}$ & $0.034^{\mathrm{b}}$ \\
\hline Creatinine & $0.75 \pm$ & $0.93 \pm 0.14^{\mathrm{a}}$ & $0.63 \pm$ \\
& $0.018^{\mathrm{b}}$ & & $0.075^{\mathrm{b}}$ \\
\hline Urea & $30 \pm 2.50^{\mathrm{b}}$ & $49 \pm 2.67^{\mathrm{a}}$ & $41 \pm 2.31^{\mathrm{ab}}$ \\
\hline
\end{tabular}

Values are the means of eight rats. ${ }^{\text {ab }}$ Within rows, between control and treated animals, means with different superscript letters differ significantly $(\mathrm{P}<0.05)$.

However, treatment of alloxan-diabetic rats with the juices of onion reduced their plasma glucose levels by $70 \%$ compared with the diabetic group. In alloxan-diabetic rats the activities of plasma AST, ALT, LDH, AlP and Acp were significantly ( $\mathrm{p}<0.05$ ) increased by 49, 60, 37, 51 and 58\%, respectively, relative to their normal levels (Table 2).

Table 2: Assay of plasma enzyme activities and thiobarbituric acid-reactive substances (TBARS) in control, diabetic, and diabetic treated male rats with onion $(\mathrm{O})$ (Means $\pm \mathrm{SE}$ )

\begin{tabular}{|l|c|c|c|}
\hline Parameters & Control & Diabetic & Diabetic + O \\
\hline LDH (U/l) & $1034 \pm 92^{\mathrm{b}}$ & $1494 \pm 54^{\mathrm{a}}$ & $1203 \pm 68^{\mathrm{ab}}$ \\
\hline AlP (U/l) & $45 \pm 3.03^{\mathrm{c}}$ & $73 \pm 3.40^{\mathrm{a}}$ & $49 \pm 2.70^{\mathrm{b}}$ \\
\hline AcP (U/l) & $10.3 \pm 0.78^{\mathrm{c}}$ & $18.8 \pm 0.68^{\mathrm{a}}$ & $13.7 \pm 0.81^{\mathrm{b}}$ \\
\hline GST (lmol/h) & $0.64 \pm$ & $0.62 \pm$ & $0.66 \pm$ \\
& $0.015^{\mathrm{a}}$ & $0.009^{\mathrm{a}}$ & $0.028^{\mathrm{a}}$ \\
\hline TBARS & $0.75 \pm 0.06^{\mathrm{b}}$ & $0.93 \pm 0.05^{\mathrm{a}}$ & $0.80 \pm 0.05^{\mathrm{a}}$ \\
(nmol/ml) & & & \\
\hline AST (U/dl) & $43 \pm 1.02^{\mathrm{c}}$ & $61 \pm 2.34^{\mathrm{a}}$ & $46 \pm 2.95^{\mathrm{bc}}$ \\
\hline ALT (U/dl) & $49 \pm 2.07^{\mathrm{c}}$ & $78 \pm 4.37^{\mathrm{a}}$ & $57 \pm 5.96^{\mathrm{bc}}$ \\
\hline
\end{tabular}

Values are the means of eight rats. ${ }^{\text {abc }}$ Within rows, between control and treated animals, means with different superscript letters differ significantly $(\mathrm{P}<0.05)$.

In contrast, the activities of AST, ALT, LDH, AlP and AcP were significantly $(\mathrm{p}<0.05)$ decreased in the liver tissue of alloxan-diabetic rats (Table 3 ) by $47 \%, 38 \%, 41 \%, 35 \%$ and $36 \%$, respectively and increased in testes by $38 \%, 32 \%, 35 \%, 31 \%$ and $33 \%$, respectively compared to the control values (Table 4).
Table 3: Assay of liver enzyme activities and thiobarbituric acid-reactive substances (TBARS) in control, diabetic, and diabetic treated male rats with onion $(\mathrm{O})$ (Means $\pm \mathrm{SE})$

\begin{tabular}{|l|c|c|c|}
\hline Parameters & Control & Diabetic & Diabetic + O \\
\hline LDH $^{* *}$ & $2146 \pm 176^{\mathrm{a}}$ & $1236 \pm 61^{\mathrm{c}}$ & $1729 \pm 92^{\mathrm{b}}$ \\
\hline AlP $^{*}$ & $328 \pm 23.0^{\mathrm{a}}$ & $209 \pm 7.6^{\mathrm{c}}$ & $284 \pm 10.2^{\mathrm{ab}}$ \\
\hline AcP $^{\mathrm{a}}$ & $17.1 \pm 1.20^{\mathrm{a}}$ & $10.3 \pm 0.71^{\mathrm{c}}$ & $14.5 \pm 0.97^{\mathrm{ab}}$ \\
\hline GST $^{* *} *$ & $0.90 \pm$ & $1.55 \pm$ & $1.45 \pm 0.049^{\mathrm{b}}$ \\
& $0.052^{\mathrm{c}}$ & $0.059^{\mathrm{a}}$ & \\
\hline TBARS $^{* * * *}$ & $24.4 \pm 1.14^{\mathrm{b}}$ & $29.6 \pm 1.10^{\mathrm{a}}$ & $25.1 \pm 0.50^{\mathrm{b}}$ \\
\hline AST $^{*}$ & $137 \pm 3.35^{\mathrm{a}}$ & $77 \pm 3.24^{\mathrm{c}}$ & $109 \pm 2.13^{\mathrm{b}}$ \\
\hline ALT $^{\mathrm{b}}$ & $113 \pm 5.74^{\mathrm{a}}$ & $68 \pm 3.38^{\mathrm{c}}$ & $97 \pm 5.99^{\mathrm{b}}$ \\
\hline
\end{tabular}

Values are the means of eight rats. ${ }^{\text {abc }}$ With in rows, between control and treated animals, means with different superscript letters differ significantly $(\mathrm{P}<0.05)$.

* IU/mg: international unit, the amount of the enzyme that under defined assay conditions will catalyze 1 mole of substrate per minute, per mgprotein

** IU/g: international unit, the amount of the enzyme that under defined assay conditions will catalyze 1 mole of substrate per minute, per gramtissue *** GST specific activity: $1 \mathrm{~mol} / \mathrm{h} / \mathrm{mg}$ protein. **** TBARS is expressed as $\mathrm{nmol} / \mathrm{g}$ tissue.

Table 4: Assay of testes enzyme activities and thiobarbituric acid-reactive substances (TBARS) in control, diabetic, and diabetic treated male rats with onion $(\mathrm{O})$ (Means $\pm \mathrm{SE})$

\begin{tabular}{|l|c|c|c|}
\hline Parameters & Control & Diabetic & Diabetic + O \\
\hline LDH $^{* *}$ & $1008 \pm 82^{\mathrm{b}}$ & $1390 \pm 67^{\mathrm{a}}$ & $1122 \pm 62^{\mathrm{ab}}$ \\
\hline AlP $^{*}$ & $466 \pm 19^{\mathrm{b}}$ & $615 \pm 22^{\mathrm{a}}$ & $527 \pm 67^{\mathrm{ab}}$ \\
\hline AcP $^{*}$ & $10.1 \pm 0.44^{\mathrm{b}}$ & $14.7 \pm 1.01^{\mathrm{a}}$ & $12.3 \pm 0.56^{\mathrm{b}}$ \\
\hline GST $_{* *}$ & $0.88 \pm 0.01^{\mathrm{b}}$ & $1.17 \pm 0.01^{\mathrm{a}}$ & $0.97 \pm 0.06^{\mathrm{a}}$ \\
\hline TBARS $_{* * *}$ & $15.5 \pm 0.39^{\mathrm{c}}$ & $20.1 \pm 0.76^{\mathrm{a}}$ & $18.8 \pm 0.45^{\mathrm{bc}}$ \\
\hline AST $^{*}$ & $84 \pm 5.52^{\mathrm{c}}$ & $119 \pm 6.38^{\mathrm{a}}$ & $96 \pm 4.54^{\mathrm{bc}}$ \\
\hline ALT $^{*}$ & $78 \pm 5.95^{\mathrm{b}}$ & $109 \pm 3.76^{\mathrm{a}}$ & $89 \pm 5.12^{\mathrm{ab}}$ \\
\hline
\end{tabular}

Values are the means of eight rats. abcWithin rows, between control and treated animals, means with different superscript letters differ significantly $(\mathrm{P}<0.05)$.

* IU/mg: international unit, the amount of the enzyme that under defined assay conditions will catalyze 1 mole of substrate per minute, per mgprotein.

** IU/g: international unit, the amount of the enzyme that under defined assay conditions will catalyze 1 mole of substrate per minute, per gramtissue.

*** GST specific activity: $1 \mathrm{~mol} / \mathrm{h} / \mathrm{mg}$ protein. **** TBARS is expressed as $\mathrm{nmol} / \mathrm{g}$ tissue.

Also, brain LDH activity was significantly ( $\mathrm{p}<$ 0.05 ) increased by $58 \%$ in alloxan-diabetic rats (Table 5). The present study showed that the levels of free radicals were significantly $(p<0.05)$ increased in plasma, liver, testes, brain and kidney by $28 \%, 16 \%, 22 \%, 38 \%$ and $22 \%$, respectively in alloxan-diabetic rats as compared to control 
values (Tables 2-5). While, after treatment of alloxan-diabetic rats with onion, the level of free radicals was significantly $(\mathrm{p}<0.05)$ decreased in plasma and tissues as compared with the mean value of diabetic group (Tables 2-5). In the present study the activity of GST was significantly $(\mathrm{p}<0.05)$ increased in liver, testes and kidney of both diabetic and, onion -treated diabetic rats compared with the control values (Tables 3-5).

Table 5: Assay of brain and kidney enzyme activities and thiobarbituric acid-reactive substances (TBARS) in control, diabetic, and diabetic treated male rats with onion $(\mathrm{O})$ (Means $\pm \mathrm{SE})$

\begin{tabular}{|c|c|c|c|c|}
\hline organ & Parameter & Control & Diabetic & $\begin{array}{l}\text { Diabetic } \\
+\mathrm{O}\end{array}$ \\
\hline \multirow[t]{2}{*}{ Kidney } & GST $^{* *}$ & $\begin{array}{l}0.85 \pm \\
0.027 b\end{array}$ & $\begin{array}{l}1.28 \pm \\
0.047 \mathrm{a}\end{array}$ & $\begin{array}{l}1.12 \pm \\
0.069 \mathrm{a}\end{array}$ \\
\hline & TBARS $* * *$ & $\begin{array}{l}20.7 \pm \\
0.55 \mathrm{~b}\end{array}$ & $\begin{array}{ll}28.6 & \pm \\
0.86 a & \end{array}$ & $\begin{array}{ll}26.0 & \pm \\
0.82 \mathrm{a} & \end{array}$ \\
\hline \multirow[t]{3}{*}{ Brain } & $\mathrm{LDH}^{*}$ & $\begin{array}{l}1154 \quad \pm \\
54 \mathrm{c}\end{array}$ & $\begin{array}{ll}1882 & \pm \\
84 a & \end{array}$ & $\begin{array}{l}1471 \quad \pm \\
55 \mathrm{~b}\end{array}$ \\
\hline & $\mathrm{GST}^{* *}$ & $\begin{array}{l}0.52 \pm \\
0.001 \mathrm{a}\end{array}$ & $\begin{array}{l}0.62 \pm \\
0.004 \mathrm{a}\end{array}$ & $\begin{array}{ll}0.43 & \pm \\
0.006 \mathrm{a} & \end{array}$ \\
\hline & TBARS $* * *$ & $\begin{array}{l}23.7 \\
0.80 \mathrm{c}\end{array}$ & $\begin{array}{ll}34.4 & \pm \\
1.04 \mathrm{a} & \end{array}$ & $\begin{array}{ll}26.5 & \pm \\
0.80 \mathrm{~b} & \end{array}$ \\
\hline
\end{tabular}

Values are the means of eight rats.

abcWithin rows, between control and treated animals, means with different superscript letters differ significantly $(\mathrm{P}<$ $0.05)$.

* IU/g: international unit, the amount of the enzyme that under defined assay conditions will catalyze 1 mole of substrate per minute, per gramtissue.

** GST specific activity: $1 \mathrm{~mol} / \mathrm{h} / \mathrm{mg}$ protein.

*** TBARS is expressed as $\mathrm{nmol} / \mathrm{g}$ tissue.

\section{Discussion}

The results of plasma glucose, urea, creatinine and total bilirubin (Table 1) are consistent with the finding of Augusti and Sheela (1996), Campos et al. (2003) and Demerdash et al.(2005) in rats, Kumar and Reddy (1999) in mice and Jain and Vyas (1975) in rabbits [26,27,28,29 and 30 respectively]. Tjokroprawiro et al. (1983) found a significant decrease in blood sugar level in the onion treated diabetic patients ${ }^{[31]}$. Iweala and Okeke (2005) found that onion indirectly affects atherosclerosis by reduction of hyperlipidemia, hypertension, and probably diabetes mellitus and prevents thrombus formation ${ }^{[32]}$. Augusti and Sheela (1996) reported that onion acts as an insulin secretagogue in diabetic rats ${ }^{[26]}$. Another proposed mechanism is due to spare insulin from sulfhydryl group. Inactivation of insulin by sulfhydryl group is a common phenomenon. Onion can effectively combine with compounds like cysteine and enhance serum insulin ${ }^{[33]}$. Jain and Vyas (1975) proposed that onion can act as an antidiabetic agent by increasing either the pancreatic secretion of insulin from the beta cells or its release from bound insulin ${ }^{[30]}$. Kumari and Augusti (2002) reported that S-methylcysteine sulfoxide (SMCS), isolated from onion, had antihyperglycemic and antioxidant effect. The probable mechanism of action of SMCS may be partly due to the stimulation of insulin secretion ${ }^{[34]}$. The diabetic hyperglycemia induces elevation of plasma levels of urea and creatinine which are considered as significant markers of renal dysfunction ${ }^{[35]}$. The results in Table 1 showed significant $(p<0.05)$ increase in the level of plasma urea and creatinine in the diabetic groups by $40 \%$ and $68 \%$ of control level, respectively. These results indicated that diabetes could be lead to renal dysfunction. While, after treatment of alloxan-diabetic rats with onion, the level of urea was significantly $(\mathrm{p}<0.05)$ decreased in plasma by $16 \%$ compared to the mean value of diabetic group (Table 1). Similarly, the elevation of creatinine level caused by diabetes was declined after administration of onion by $32 \%$ ( $\mathrm{p}<0.05)$ compared with the diabetic group (Table 1). These results are in agreement with other previous studies on onion ${ }^{[36]}$, root extract of panax ginseng ${ }^{[37]}$ and herbal formulation D-400 ${ }^{[38]}$. The increase in the activities of plasma AST, ALT, LDH, AlP and Acp (Table 2) indicated that diabetes may be induced hepatic dysfunction. Supporting our finding it has been found by Larcan et al. (1979) that liver was necrotized in diabetic patients ${ }^{[39]}$. Therefore, the increment of the activities of AST, ALT, LDH, AlP and AcP in plasma may be mainly due to the leakage of these enzymes from the liver cytosol into the blood stream, which 
gives an indication on the hepatotoxic effect of alloxan ${ }^{[40]}$. On the other hand, treatment of the diabetic rats with onion caused reduction in the activity of these enzymes in plasma (Table 2) compared to the mean values of diabetic group. These results are in agreement with those obtained by Ohaeri (2001) in rats ${ }^{[41]}$. The reduction in liver enzyme activities (Table 3) is mainly due to leakage of these enzymes into the blood stream as a result of alloxan toxicity which leads to the liver damage. However, treatment of alloxan diabetic groups with onion for 28 consecutive days could restore the activities of the above enzymes to their normal levels. A possible explanation for the differential effects of onion on the activities of AST, ALT, LDH, AlP and AcP in plasma and liver is that these treatments may inhibit the liver damage induced by alloxan. Furthermore, the improvement of the liver damage by oral administration of onion could be confirmed through studying their effect on the level of plasma bilirubin. The results in Table 1 showed that the experimentally induced diabetes increased ( $p<0.05$ ) the level of plasma bilirubin by $55 \%$ of control. However, onion intake produced significant $(\mathrm{p}<0.05)$ decreased in plasma bilirubin of alloxan-diabetic rats by $28 \%$ compared to the diabetic rats. Rana et al. (1996) reported that the increase in plasma bilirubin (hyper-bilirubenimia) may be resulted from the decrease of liver uptake, conjugation or increase bilirubin production from hemolysis ${ }^{[42]}$. Also, the elevation in plasma bilirubin indicates liver damage as confirmed by the changes in the activities of plasma (Table 2) and liver (Table 3) enzymes. Like many chronic diseases, diabetes is widely believed to increase oxidative stress. In diabetes an increase in oxidative stress arises due to compromise in natural antioxidant mechanisms and an increase in oxygen free radical production ${ }^{[43]}$. The induction in the levels of free radicals in alloxandiabetic rats, and the decrease in these levels after treatment of alloxan-diabetic rats with onion (Tables 2-5) are in agreement with those obtained by Zheng and Wang (2001), Erejuwa et al.,(2010), Ahmed et al. (2011), Onyeka et al., (2013) and Pitocco et al. (2010) ${ }^{[44,45,46,47}$ and 48]. Also, Pavana et al. (2009) reported that onion was effective in preventing or ameliorating oxidative stress. Maintenance of free radical levels in onion-treated diabetic animals might be due to the presence of S-methylcysteine sulfoxide in onion ${ }^{[49]}$. Glutathione S-transferases (GSTs) are a family of enzymes that catalyze the addition of the tripeptide glutathione to endogenous groups. They play an important role in the detoxification and metabolism of many xenobiotic and endobiotic compounds ${ }^{[50]}$. So far, few studies have been directed towards the influence diabetes millitus and hypoglycemic onion on the activity of GST ${ }^{[46}$ and 47 . The increment in the activity of GST (Tables 3-5) is in consistent with the induction in the generation of free radicals (Tables 2-5). Increased GST activity might be one of the defense mechanism in these animals to detoxify or neutralize the toxic metabolites, e.g. ketone bodies, generated in liver by the diabetes. Ohaeri (2001) suggested that onion oil may effectively normalize the impaired antioxidants status in streptozotocin induced-diabetes. The effects of this antioxidant may be useful in delaying the complicated effects of diabetes as retinopathy, nephropathy and neuropathy due to imbalance between free radicals and antioxidant systems. From the above results, it could be concluded that onion is able to normalize the blood glucose levels. In addition, these plant juice could ameliorate the impaired renal function, inhibit liver damage and free radicals associated with alloxan diabetes.

\section{Conclusions}

Treatment of the diabetic rats with repeated doses of onion juice could restore the changes of the glucose, kidney functions, liver enzmes and antioxident enzymes to their normal levels. The present results showed that onion juice exerted antioxidant and antihyperglycemic effects and consequently may alleviate liver and renal damage caused by alloxan-induced diabetes 


\section{References}

1. World Health Organization, Diabetes Mellitus Fact Sheet No. 138, World Health Organization, Geneva, Switzerland, 2016.

2. M. Cnop, N. Welsh, J.-C. Jonas, A. Jörns, S. Lenzen, and D. L. Eizirik, "Mechanisms of pancreatic $\beta$-cell death in type 1 and type 2 diabetes: many differences, few similarities," Diabetes, vol. 54, no. 2, pp. S97-S107, 2005.

3. J. L. Evans, I. D. Goldfine, B. A. Maddux, and G. M. Grodsky, "Are oxidative stress activated signaling pathways mediators of insulin resistance and $\beta$-cell dysfunction?" Diabetes, vol. 52, no. 1, pp. 1-8, 2003.

4. R. A. Simmons, "Developmental origins of diabetes: the role of oxidative stress," Free Radical Biology and Medicine, vol. 40, no. 6, pp. 917-922, 2006.

5. M. D. Ivorra, M. Payá, and A. Villar, “A review of natural products and plants as potential antidiabetic drugs," Journal of Ethnopharmacology, vol. 27, no. 3, pp. 243-275, 1989.

6. Banerjee, S.K., Maulik, S.K., 2002. Effect of onion on cardiovascular disorders: a review. Nutrition Journal 1 (4), 1-14.

7. Reaven, E., Wright, D., Mondon, C.E., Solomon, R., Ho, H., Reaven,G.M., 1983. Effect of age and diet on insulin secretion and insulin action in the rat. Diabetes 32, 175-180.

8. Sanchez, F.D., Game, M.J., Jimenez, I., Zarzuelo, A., 1994. Hypoglycemic activity of Juniperus “'Berries”. Plant Medicine 60, 197-200.

9. Griffiths, G., Trueman, L., Crowther, T., Thomas, B., 2002. Onions: a global benefit to health. Phytotherapy Research 17 (7), 603-615.

10. Augusti, K.T., 1996. Therapeutic values of onion (Allium cepa L.) and garlic (Allium sativum L.). Indian Journal of Experimental Biology 34, 634-640.
11. Bonaventure Chukwunonso Obi, 1 Theophine Chinwuba Okoye,1 Victor Eshu Okpashi, 2 Christiana Nonye Igwe, 3 and Edwin Olisah Alumanah2., 2016. Diabetes Research 2016, Article ID 1635361,5 pages

12. AOAC, 1990. Official Methods of Analysis of the Association of Official Analytical Agricultural Chemists, 13th ed. Benjamin, Franklin Station, Washington, DC.

13. Reitman, S., Frankel, S.A., 1957. Colorimetric method for the determination of serum glutamic oxaloacetic and glutamic pyruvic transaminases. American Journal of Clinical Pathology 28, 56-63.

14. Cabaud, P.C., Wroblewski, F., 1958. Calorimetric measurement of lactate dehydrogenase activity of body fluids. Journal of Clinical Pathology 30, 234-236

15. Principato, G.B., Asia, M.C., Talesa, V., Rosi, G., Giovannini, E.,1985. Characterization of the soluble alkaline phosphatase from hepatopancreas of Squilla mantis L. Comparative Biochemistry and Physiology 80B, 801-804.

16. Moss, D.W., 1984. In: Bergmeyer, H.U. (Ed.), third ed., Methods of Enzymatic Analysis, vol. 4 Verlag-Chemie, pp. 92106.

17. Habig, W.H., Pabst, M.J., Jakoby, W.B., 1974. Glutathione Stransferases. The first enzymatic step in mercapturic acid formation. Journal of Biological Chemistry 249, 7130-7139.

18. Tappel, A.L., Zalkin, H., 1959. Inhibition of lipid peroxidation in mitochondria by vitamin E. Archives of Biochemistry and Biophysics 80, 333-336.

19. Lowry, O.H., Rosebrough, N.J., Farr, A.L., Randall, R.J., 1951. Protein measurement with the Folin Phenol Reagent. Journal of Biological Chemistry 193, 269-275.

20. Trinder, P., 1969. Determination of glucose in blood using glucose oxidase 
with an alternative oxygen acceptor. Annals of Clinical Biochemistry 6, 24-27.

21. Patton, C.J., Crouch, S.R., 1977. Spectrophotometeric and kinetics investigation of the Berthelot reaction for determination of ammonia. Analytical Chemistry 49, 464469.

22. Henry, R.J., Cannon, D.C., Winkelman, J.W., 1974. Clinical Chemistry Principles and Techniques, 11th ed. Happer and Row Publishers, New York, p. 1629.

23. Pearlman, F.C., Lee, R.T.Y., 1974. Detection and measurement of total bilirubin in serum, with use of surfactants as solubilizing agents. Clinical Chemistry 20, 447-453.

24. Steel, R.G.D., Torrie, J.H., 1981. Principle and Procedure of Statistics. A Biometrical Approach, second ed. Mc Gvaus-Hill Booh Company, New York, US.

25. SAS, Statistical Analysis System., 1986. SAS User_s Guide: Statistics, Version 5 Edition. SAS Inst. Inc., Cary, NC, USA.

26. Augusti, K.T., Sheela, C.G., 1996. Antiperoxide effect of S-allyl cysteine sulfoxide, a insulin secretagogue, in diabetic rats. Experientia 52, 115-120.

27. Campos, K.E., Diniz, Y.S., Cataneo, A.C., Faine, L.A., Alves, M.J.,Novelli, E.L., 2003. Hypoglycaemic and antioxidant effects of onion, Allium cepa: dietary onion addition, antioxidant activity and hypoglycaemic effects on diabetic rats. International Journal of Food Science and Nutrition 54 (3), 241-246.

28. F. M. El-Demerdash, M. I. Yousef, and N. I. A. El-Naga, "Biochemical study on the hypoglycemic effects of onion and garlic in alloxan-induced diabetic rats," Food and Chemical Toxicology, vol. 43, no. 1, pp. 57-63, 2005.I

29. Kumar, G.R., Reddy, K.P., 1999. Reduced nociceptive responses in mice with alloxan induced hyperglycemia after onion
(Allium cepa) treatment. Indian Journal of Experimental Biology 37, 662-666.

30. Jain, R.C., Vyas, C.R., 1975. Onion in alloxan-induced diabetic rabbits. American Journal of Clinical Nutrition 28, 684-685.

31. Tjokroprawiro, A., Pikir, B.S., Budhiarta, A.A., Pranawa, S.H,Donosepoetro, M., Budhianto, F.X., Wibowo, J.A., Tanuwidjaja, M., Pangemanan, M., 1983. Metabolic effects of onion and green beans on diabetic patients. Tohoku Journal of Experimental Medicine 141, 671-676.

32. E. E. J. Iweala and C. U. Okeke, "Comparative study of the hypoglycemic and biochemical effects of Catharanthu-sroseus (Linn) G. apocynaceae (Madag-ascar periwig-ggnkle) and chlorpropamide (diabinese) on alloxan-induced diabetic rats," Biokemistri, vol 17, no. 2, pp 149156, 2005

33. Mathew, P.T., Augusti, K.T., 1973. Studies on the effect of onion (diallyldisulphide-oxide) on alloxan diabetes 1 . Hypoglycaemic action and enhancement of serum insulin effect and glycogen synthesis. Indian Journal of Biochemistry and Biophysics 10, 209-212.

34. Kumari, K., Augusti, K.T., 2002. Antidiabetic and antioxidant effects of $\mathrm{S}$ methyl cysteine sulfoxide isolated from onions (Allium cepa Linn) as compared to standard drugs in alloxan diabetic rats. Indian Journal of Experimental Biology 40, 1005-1009

35. Almdal, T.P., Vilstrup, H., 1988. Strict insulin treatment normalizes the organic nitrogen contents and the capacity of urea$\mathrm{N}$ synthesis in experimental diabetes in rats. Diabetologica 31, 114-118.

36. Babu, P.S., Srinivasan, K., 1999. Renal lesions in streptozotocininduced diabetic rats maintained on onion and capsaicin containing diets. Journal of Nutritional Biochemistry 10 (8), 477-483 
37. Badr El-Din, N.K., 1997. Effect of panaxginsing extract on the nephrotoxicity of streptozotocin-induced experimental diabetes. Egyptian Journal Biochemistry 15 (1 and 2), 29-52.

38. Dubey, G.P., Dixit, S.P., Singh, A., 1994. Alloxan-induced diabetes in rabbits and effect of a herbal formulation D-400. Indian Journal of Pharmacology 26(3),225226.

39. Larcan, A., Lambert, H., LaprevoteHeully, M.C., Delorme, N., 1979. Light and electron microscopic study of hepatic lesions in the course of hyperlactatemia in diabetic patients. Diabetes Metabolism 5, 103-112.

40. Navarro, C.M., Montilla, P.M., Martin, A., Jimenez, J., Utrilla, P.M., 1993. Free radicals scavenger and antihepatotoxic activity of Rosmarinus. Plant Medicine 59, 312-314.

41. Ohaeri, O.C., 2001. Effect of onion oil on the levels of various enzyme in the serum and tissue of streptozotocin diabetic rats. Bioscience and Reproduction 21, 19-24.

42. Rana, S.V., Rekha, S., Seema, V., 1996. Protective effects of few antioxidants on liver function in rats treated with cadmium and mercury. Indian Journal of Experimental Biology 34, 177-179.

43. Baynes, J.W., Thorpe, S.R., 1999. Role of oxidative stress in diabetic complications. Diabetes 48, 1-9.

44. W. Zheng and S. Y. Wang, "Antioxidant activity and phenolic compounds in selected herbs," Journal of Agricultural and Food Chemistry, vol. 49, no. 11, pp. 5165-5170, 2001

45. O. O. Erejuwa, S. A. Sulaiman, M. S. Abdul Wahab, S. K. N. Salam, M. S. M. Salleh, and S. Gurtu, "Antioxidant protective effect of glibenclamide and metformin in combination with honey in pancreas of streptozotocin-induced diabetic rats," International Journal of Molec- ular Sciences, vol. 11, no. 5, pp. 20562066, 2010.

46. M. M. Ahmed, A. E. Ahmed, S. A. G. Hala, M. M. Gehan, and A. A. Fahad, "Protective effects of simvastatin, an HMG-CoA reductase inhibitor, against oxidative damage in experimental diabetic rats," International Journal of PharmTech Research, vol 3, no 3, pp 1780-1795, 2011.

47. C. A. Onyeka, A. A. Nwakanma, A. A. Bakare et al., "Hypoglycemic, antioxidant and hepatoprotective activities of ethanolic root bark extract of Chrysophyllumalbidum in alloxan-induced diabetic rats," Bangladesh Journal of Medical Science, vol. 12, no. 3, pp. 298-304, 2013

48. D. Pitocco, F. Zaccardi, E. Di Stasio et al., "Oxidative stress, nitric oxide, and diabetes," Review of Diabetic Studies, vol. 7, no. 1, pp. 15-25, 2010

49. P. Pavana, S. Sethupathy, K. Santha, and S. Manoharan, "Effects of Tephrosiapurpurea aqueous seed extract on blood glucose and antioxidant enzyme activities in streptozotocin induced diabetic rats," African Journal of Traditional, Complementary and Alternative Medicines, vol. 6, no. 1, pp. 78-86, 2009

50. Ji, X., Zhang, P., Armstrong, R.N., Gilliland, G.L., 1992. The Threedimensional structure of a glutathione S-transferase from the $\mathrm{Mu}$ gene class. Structural analysis of the binary complex of isoenzyme 3-3 and glutathione at 2.2- $\mathrm{A}^{\circ}$ resolution. Biochemistry 31, 1016910184. 